\title{
Effect of urbanization on stream hydraulics
}

Running head: Urbanization and stream hydraulics

\author{
Desmond O. Anim ${ }^{1} *$, Tim D. Fletcher ${ }^{1}$, Geoff J. Vietz ${ }^{1}$, Gregory B. Pasternack ${ }^{2}$, Matthew J. \\ Burns ${ }^{1}$ \\ ${ }^{1}$ Waterway Ecosystem Research Group, School of Ecosystem and Forest Science, The \\ University of Melbourne, Burnley, Victoria 3121, Australia \\ ${ }^{2}$ University of California Davis, Land, Air and Water Resources, Davis, CA, 95616, USA \\ *Corresponding Author: email: desofosa@gmail.com
}

\begin{abstract}
Urbanization results in major changes to stream morphology and hydrology with the latter often cited as a primary stressor of urban stream ecosystems. These modifications unequivocally alter stream hydraulics, but little is known about such impacts. Hydraulic changes due to urbanization were demonstrated using two-dimensional hydrodynamic model simulations, comparing urban and non-urban stream reaches. We investigated three ecologically relevant hydraulic characteristics; bed mobilization, retentive habitat and floodplain inundation, using hydraulic metrics bed shear stress, shallow slow-water habitat (SSWH) area, and floodplain inundation area. We hypothesized that urbanization would substantially increase bed mobilization, decrease retentive habitat and due to increased channel size would decrease floodplain inundation. Relative percent area of bed disturbance
\end{abstract}

This is the author manuscript accepted for publication and has undergone full peer review but has not been through the copyediting, typesetting, pagination and proofreading process, which may lead to differences between this version and the Version of Record. Please cite this article as doi: $10.1002 /$ rra.3293

This article is protected by copyright. All rights reserved. 
was four times higher, compared with that of the non-urban stream at bankfull discharge $\left(Q_{b k f}\right)$. SSWH availability rapidly diminished in the urban stream as discharge increased, with SSWH area and patch size two times smaller than the non-urban stream for a frequently

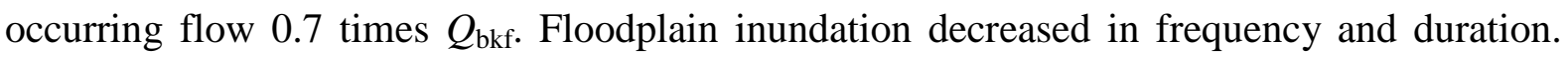
These results demonstrate changes in hydraulics due to urbanization that may impact on physical habitat in streams. New "water sensitive" approaches to stormwater management could be enhanced by specification of hydraulic regimes capable of supporting healthy stream habitats. We propose that a complete management approach should include the goals of restoration and protection of natural hydraulic processes, particularly those that support ecological and geomorphic functioning of streams.

Keywords: urbanization; streams; hydraulic; stormwater runoff; channel morphology; flow regimes;

stream

management 


\section{INTRODUCTION}

Most streams draining urban catchments exhibit signs of ecological degradation (Morley \& Karr, 2002; Wenger et al., 2009; King et al., 2011). Recent studies point to urban stormwater runoff as a primary degrader of stream ecosystems (Ladson et al., 2006; Burns et al., 2012; Walsh et al., 2012; Vietz et al., 2014). When urban stormwater runoff (runoff from impervious areas) is conveyed directly to streams via conventional stormwater drainage, many impacts occur including increased frequency of hydrologic and water quality disturbance, as well as channel geomorphology alteration (Brabec et al., 2002; Walsh et al., 2012; Vietz et al., 2015). Combined, these impacts result in poor in-stream ecological condition, often referred to as the 'urban stream syndrome' (Walsh et al., 2005c). Whilst evaluating multiple stressors is an area of active research (Meyer et al., 2005; Wenger et al., 2009), the frequent disturbance through regular delivery of polluted stormwater runoff is considered a 'master variable' influencing stream health (Walsh et al., 2012).

The altered flow regimes and consistent changes to stream ecosystems following urbanization particularly stormwater management as an agent is now well recognised (Paul \& Meyer, 2008; Walsh et al., 2012). It is characterised by: 1) frequent flashy (with increased magnitude, volume, steep rising and falling limbs) hydrograph as a result of impervious surfaces directly connected to the streams; 2) increased frequency of flows below the longterm mean daily flow rate; and 3) decreased summer and winter baseflow magnitude because of reduced infiltration (Walsh et al., 2005b; Burns et al., 2012). Consequently, with the increased frequency, magnitude and duration of altered flows, urban stormwater runoff is considered highly effective geomorphic agent. Together with changes in sediment supply, urban streams in response to altered hydrology experience widespread adjustments in the stream channel including enlargement, deepening and simplification of channel morphology (Bledsoe \& Watson, 2001; Reinfelds et al., 2004; Hawley et al., 2012; Vietz et al., 2014). These changes are reported to increase as the level of connected imperviousness increased (Hawley \& Bledsoe, 2011). For example, Vietz et al. (2014) found a correlation between connected imperviousness, and geomorphic change in urban streams. They reported that urban streams even with less than $\sim 3 \%$ connected impervious area showed degraded channel 
with less variability, unless the channels are subject to constraints such as bank or bedrock protection. Others have also correlated hydrological changes driven by increases in impervious surfaces to changes channel form and stability (see Chin, 2006; Vietz et al., 2016).

This has resulted in urban stream degradation being considered a predominantly hydrological problem (Walsh, 2004; Roy et al., 2005; Burns et al., 2012), albeit other direct in-stream physical intervention works such as channelization, channel straightening is also recognized to cause channel degradation (Chin, 2006). This has resulted in driving research to understand the mechanisms influencing degradation, and to inform protection and restoration approaches (Wenger et al., 2009). Thus, substantial effort has been given to using hydrological-based approaches for assessing instream flow regimes and understanding stream responses to guide informed management decisions (Wenger et al., 2009; Burns et al., 2012). It has been hypothesized that frequent flow disturbance is strongly linked to stream ecosystem degradation, including morphological and ecological impairment (Walsh et al., 2005a; Vietz et al., 2014). This suggests the need to address frequent flow input from particularly impervious areas in the urban catchment.

While hydrology is a primary stressor, consideration of hydrology alone fails to recognise the role of channel morphology in translating flow into hydraulic characteristics, such as depth and velocity. The ecological relevant of hydraulic conditions produced by the interaction of streamflow and in-channel physical features is widely recognised (Kemp et al., 2000; Turner \& Stewardson, 2014). Stream hydraulic conditions are known to drive ecosystem structure and function (Statzner \& Higler, 1986; Jowett, 2003; Brooks et al., 2005). The relationships between reach-scale hydraulics metrics have been used as basis to inform environmental flow management (Acreman \& Dunbar, 2004; Turner \& Stewardson, 2014) and also to quantify ecologically important stream functioning (Steuer et al., 2009). For example, the duration and area of habitat availability and refuge for biota provided within the wetted channel have primarily been investigated which is mostly essential determinant of species population dynamics (Gibbins et al., 2007; Lobera et al., 2017). Particularly, shallow slow-water habitats (SSWH) are vulnerable to hydrological alteration and have been shown to reduce fish 
abundance, macroinvertebrates that depend on SSWH as refugia and organic matter retention (Vietz et al., 2013). Another example is the bed shear stress usually examined to address refuge concept for benthic biota where duration of reach-average shear stress above specific threshold are used to assess possible disturbance of biota from bed exposure (Jorde \& Bratrich, 1998; Mérigoux \& Dolédec, 2004). In addition, the frequency, duration and extent of floodplains flows have been linked with flow-mediated exchange of energy, organic matter and biota (Cienciala \& Pasternack, 2017). Floodplains flows dynamics produce important habitat supporting biota such as fish utilizing it as spawning and rearing habitat (Gorski et al., 2011). In most aquatic ecosystem flow investigation, the spatial and temporal variabilities of these hydraulic conditions have been closely linked to the ecological condition (Humphries et al., 2006; Vietz et al., 2013) as well as geomorphic processes (Strom et al., 2016). Thus, directly linking hydrologic indicators to stream ecosystem impairment without considering hydraulics, fails to account for the direct causal physical mechanisms driving stream degradation and habitat quality (Escobar-Arias \& Pasternack, 2010).

Recent studies have argued that environmental flow evaluations must go beyond just hydrologic assessment and include hydrogeomorphic processes that are directly linked to the needs of the aquatic ecosystem (e.g., Wohl et al., 2015; Yarnell et al., 2015). In the attempts to understand the mechanistic pathways of urban-induced changes leading to stream degradation to inform management, studies have rarely considered the hydraulic responses beyond a general understanding of an increase in stream power. It is often the hydraulic conditions that influence biota and ecosystem functioning. That the relationship between hydraulics and instream form and function are often used to speculate the mechanisms influencing ecological structure and functions points to the importance of exploring these relationships. However, there is limited understanding of how the hydraulic conditions, particularly those relevant to ecosystem health, are influenced by the compounded urbaninduced hydrological alterations alongside morphology change. The understanding of the altered hydraulic environment in urban streams currently provides a poor foundation for protection or restoration, i.e. the relative role of addressing hydrology or channel morphology. Since the hydraulic conditions are poorly quantified they are rarely a focus for 
management, leading to suggestions that this may be a reason for the lack of desired ecological improvements (Clark et al., 2008; Violin et al., 2011).

In this study, we aimed to evaluate hydraulic changes in an urban stream as a result of altered catchment hydrology and channel morphology. To investigate this, two-dimensional (2D) hydrodynamic modelling was used to characterize and compare hydraulics in urban and nonurban reaches of the same stream. We characterized the degree of hydraulic change using three ecologically relevant metrics that describe (i) the extent of the channel bed disturbance, (ii) the hydraulic habitat availability (using SSWH); and (iii) floodplain inundation (which drives hydrologic connectivity between stream channels and floodplains). These hydraulic metrics are important indicators for aquatic ecosystem and biotic functioning (McCabe \& Gotelli, 2000; Paterson \& Whitfield, 2000; King et al., 2003; Brooks et al., 2005). Our study aims to underpin a better mechanistic understanding of the relationships between urbaninduced stormwater runoff and degradation of stream ecosystems and thus help improve the outcomes of stream restoration and protection activities.

\section{METHODS}

Field data collection was performed to characterize the fluvial terrain and hydrology of two stream reaches to enable mechanistic, 2D modeling over a range of discharges. Hydraulic calibration and validation data were also collected. Two-dimensional hydraulic models were produced using TUFLOW 2D. Outputs of bed shear stress, velocity and depth were obtained from steady flow simulations. Results were analyzed to assess bed disturbance pattern, hydraulic habitat availability, and floodplain inundation extent. Further details of the study sites and field data collection are provided in Supplementary Materials.

\subsection{Study sites}

The study was carried out on Cardinia Creek, which flows 34km south to Western Port Bay in south-eastern Melbourne, Australia (Figure 1). Two study reaches were selected to physically represent and compare non-urban and urban settings, referred to herein as the 'non-urban site' and 'urban site' respectively (Table 1). The non-urban site, located $6 \mathrm{~km}$ upstream of the urban site is a comparatively intact and complex naturally meandering 
channel with a sand-gravel bed, well-defined riffle-pool, benches and point bar morphological features. The urban site has a relatively simplified low-gradient, sand-gravel bed channel morphology, and exhibits less complexity both in planform and cross-profile. Estimated average bankfull width dimensions from LiDAR along the Cardinia creek segments draining non-urban portions of the Cardinia Shire catchment to the segments draining the increasingly urbanized downstream portions indicated a progressive change in channel dimensions and planform as the stream move towards the urban areas (see figure in Supplementary materials as Figure S1). This is typical of urbanized streams which tends to have wider channels (through incision and bank erosion from increased runoff) (Walsh, 2004; Hawley \& Bledsoe, 2011). While the urban site channel was selected to represent a channel predominantly impacted by urban-induced hydrological changes, a section of the reach flows under a bridge which potentially could have somehow influenced the current channel morphology. This site represents a channel typical of those draining urban catchments in this region.

\subsection{Data collection}

Detailed topographic surveys and hydrology data were collected on each study reach to enable 2D modelling. Surveying covered channel and floodplain areas. It was used to derive a DEM to elevate the computational mesh for each reach. Hydrologic data provided streamflow statistics and enabled the selection of the range of flows to be modelled. Hydraulic data were also sampled for model calibration and validation.

\subsubsection{Channel topography}

At each site, a 100-m study reach was selected corresponding to about 20 times bankfull channel width. Topographic and bathymetric data were gathered using a Sokkia Set $5 \mathrm{X}$ total station and Leica Viva GS15 GNSS receiver. Survey data described the channel bed and banks, water surface elevation (WSE), wet/dry edge boundaries. The channel bed was 
surveyed with a lateral and longitudinal frequency of approximately $0.5 \mathrm{~m}$ for both sites. The particle size distribution of bed materials was determined by pebble counts (Wolman, 1954) wherein the $b$-axis of a minimum of 100 particles was measured. A representative median size $\left(\mathrm{D}_{50}\right)$ was extracted from the particle size distribution for each site.

\subsubsection{Hydrology}

Water levels were monitored at the two study sites for one year using capacitive water level sensors (ODYSSEY® MP System). The water level data were converted to discharge by means of stage-discharge rating curves specifically estimated for the two study reaches based on direct gauging (Figure 2). The sampling period provides a good representation of a typical hydrologically average year in the catchment. For each discharge gauging, WSE longitudinal profiling was done at $20 \mathrm{~m}$ intervals along both banks for each site. Further hydrologic detail is provided in Supplementary Materials.

\subsection{Hydraulic modelling}

Hydraulic simulations were undertaken with the TUFLOW 2D model that solves the full twodimensional, depth-averaged momentum and continuity equations for free surface flow (Syme, 2001). A computational mesh was built with the bathymetric survey data for each site with $\sim 0.3 \mathrm{~m}$ grid size. The computational domain was extended about $20 \mathrm{~m}$ in both upstream and downstream directions to reduce the impact of flow and boundary assumptions on model results in the priority region of interest. Model input and boundary conditions for simulation runs were inflow discharge and corresponding measured downstream WSE. The model was run in a steady-state mode based on representative flows observed for each site during the study period for discharges ranging from 0.04 to $3.35 \mathrm{~m}^{3} / \mathrm{s}$, corresponding to 2-99 \% of time discharge $(Q)$ exceedance. This range of simulated discharges represents $0.05-4$ times and 0.02-2 times bankfull discharge $\left(Q_{\mathrm{bkf}}\right)$ for the non-urban and urban site respectively.

\subsection{Model calibration and validation}

Model calibration was achieved by manipulation of the Manning's $n$ values to match observed WSE profiles. Model simulations were validated for flows ranging from 0.1-0.5 and 
0.1-0.3 times $Q_{b k f}$ for non-urban and urban sites, respectively, using measured fixed-point depth and velocity sampled by wading. This was achieved by quantitatively comparing observed versus modelled values in the direction of flow. Calibration and validation approach and metrics as well as their threshold values are detailed in the Supplementary Material.

\subsection{Habitat mapping and bed shear analysis}

Bed shear stress outputs from the 2D model simulations were analyzed to compare the two sites for their relative potential for bed particle entrainment at given flows. The nondimensionalized Shields Stress $\left(\tau^{*}\right)$ was used as a quantitative metric of the stability of the channel bed (Pasternack, 2011), estimated from TUFLOW's bed shear stress results in each grid cell as:

$$
\tau *=\frac{\tau_{o}}{D\left(\gamma_{s}-\gamma_{w}\right)}
$$

where $\tau_{o}$ is the bed shear stress computed by TUFLOW, $D$ is the representative particle size of the channel bed (taken as $\mathrm{D}_{50}$ in this study), $\gamma_{s}$ is the unit weight of bed particle and $\gamma_{w}$ is the unit weight of water. Shields stress values were then classified based on bed particle mobility thresholds defined by Lisle et al. (2000), where $\tau^{*}<0.03$ indicates stable bed or no mobility and $\tau^{*}$ between 0.03 and 0.06 indicates intermittent entrainment, and $\tau^{*}>0.06$ indicate likely bed particle entrainment (e.g., Buffington \& Montgomery, 1997; EscobarArias \& Pasternack, 2010). Critical bed shear stress $\left(\tau_{o}^{*}\right)$ and $\tau^{*}$ was estimated using a single grain size $\left(D_{50}=6 \mathrm{~mm}\right.$ for the urban site $)$ for both sites.

For SSWH mapping and assessment, ArcGIS (Esri ArcGIS desktop 10.2) was used to process and examine the depth and depth-average velocity outputs generated by the model simulations. The outputs for the modeled 100-m domain at each simulated discharge were analyzed and composite grid maps of velocity-depth outputs generated. The SSWH areas were mapped by categorizing the grid cells that fell within a depth class of $0-0.3 \mathrm{~m}$ and velocity class of $0-0.2 \mathrm{~ms}^{-1}$. While different combinations of depth and velocity classes have been shown to be important to instream hydraulic habitat requirement for some species or some life stages, the SSWH depth and velocity class considered here is reported to be 
preferred, particularly by benthic macroinvertebrates in small streams (Shearer et al., 2015) and fish (Milhous \& Nestler, 2016). The SSWH sub-metrics included the total SSWH patch area, mean SSWH patch size, and SSWH patch density (number of SSWH patches divided by the channel length) (McGarigal \& Marks, 1995).

The area of delineation for the floodplain inundation analysis was limited to a buffer of $10 \mathrm{~m}$ of the floodplain surface on each side of the stream channel. This is necessitated by the focus on channel changes due to hydrologic change (i.e. larger capacity urban channel) rather than imposed management changes (i.e. earthworks to restrict the floodplain). The approach used here was to analyzed inundation extent and frequency in relation to discharge associated with the $0.3 \%, 2 \%, 5 \%, 10 \%$ and $15 \%$ of time discharge exceeded. Although the $2 \mathrm{D}$ simulations and hydraulic assessment were undertaken for different $Q$, for brevity in reporting the results, the maps for the metrics (SSWH, Shields Stress) for the two sites were evaluated for baseflow, median, $Q_{\mathrm{bkf}}$ and $2 Q_{\mathrm{bkf}}$ discharges.

\subsection{Data analysis}

The impacts of urbanization were assessed by looking at the increase or decrease of metrics as a function of discharge relative to non-urban conditions. The magnitude of these changes for each flow's wetted area was examined corresponding to a threshold value. For instance, the degree of bed disturbance was examined in relation to thresholds for bed material entrainment such as 0.03 or 0.06 for Shields stress. 2D maps of Shields stress, SSWH and floodplain inundation were generated to assess patch behaviour and evaluate the extent of any longitudinal changes. Changes as a function of discharge can be expansion, contraction, shifting and emergence from non-existence (Brown et al., 2016).

\section{RESULTS}

\subsection{Model performance}


Comparing observed fixed-point velocity and depth data versus model predicted conditions demonstrate satisfactory 2D model performance, with the points generally falling along a 1:1 line. See results, including figure (Figure S1) in Supplementary Materials.

\subsection{Benthic disturbance}

\subsubsection{Bed shear stress patterns}

The two study sites displayed different $\tau_{o}$ patterns, owing to their reach-scale morphological differences. Both sites exhibit increased values of reach-averaged and maximum $\tau_{o}$ as $Q$ increased. At very low $Q$ the rates appear similar, but then differ substantially at the urban site getting closure to $Q_{\mathrm{bkf}}$, where for non-urban stream values stay relatively flat or increase marginally (Figure 3).

The non-urban site showed the most stable bed with a reach-average $\tau^{*}$ of 0.02 at $Q_{\text {bkf }}$, below the critical range of entrainment ( 0.04) compared to 0.09 for the urban site. There was a sharp increase in the portion of the wetted benthic area that is likely to have particles in full motion at the urban site as $Q$ increases, approximately $0.3-0.7 \mathrm{x} Q_{\mathrm{bkf}}$, representing flows exceeded between 5-25\% of the time (Figure 4). In contrast, the relative percent of the wetted bed area potentially moving in the non-urban site remained small with increasing $Q(6 \%$ at $\left.Q_{\mathrm{bkf}}\right)$ and begins to increase steadily for $Q$ around $1.5 \mathrm{x} Q_{\mathrm{bkf}}$. This means that a greater portion of the non-urban site channel bed retained low bed shear stress even as $Q$ increased.

The frequency and magnitude of bed disturbance over the study period were predicted to be substantially greater in the urban site than non-urban site (Figure 5). The period that the daily maximum $\tau_{o}$ was equal to or exceeded the estimated $\tau_{o}^{*}\left(4 \mathrm{~N} / \mathrm{m}^{2}\right)$ was 120 days/year in the urban site compared to 35 days/year in the non-urban site. For these periods, the maximum $\tau_{o}$ at the urban site increases by a factor of 2-4. The estimated mean annual maximum $\tau_{o}$ was $2.79 \mathrm{~N} / \mathrm{m}^{2}$ and $5.67 \mathrm{~N} / \mathrm{m}^{2}$ and the annual mean $\tau_{o}$ was $0.78 \mathrm{~N} / \mathrm{m}^{2}$ and $1.75 \mathrm{~N} / \mathrm{m}^{2}$ for the nonurban and urban site respectively.

\subsubsection{The spatial distribution of bed disturbance}


Figure 6 shows planform maps of $\tau^{*}$ patch pattern for each site and across four discharges representing baseflow, median discharge, $Q_{\mathrm{bkf}}$ and $2 Q_{\mathrm{bkf}}$ respectively. Each site had spatially discrete regions of high bed disturbance and different patterns in how $\tau^{*}$ changes with $Q$. Coherent areas of both decreases and increases in $\tau^{*}$ were observed as flow increases. Patches of $\tau^{*}$ showed spatial patterns of shift, expansion, and contraction with increasing discharge. These changing patterns were variable in both lateral and longitudinal dimensions, showing diverse patch sizes and shapes. The $\tau^{*}$ was substantially higher in the urban channel compared to the non-urban channel at high $Q$.

In the non-urban channel, greater variations in channel width and bed geometry mediated where areas of high $\tau^{*}$ were observed to shift as $Q$ increased. At $Q<Q_{\mathrm{bkf}}$, areas of high $\tau^{*}$ in the channel were mostly found at meander bends and topographic highs in the main channel. Low terrain relief of the adjacent banks at the bends alleviated a fast expansion in the area of high $\tau^{*}$ as discharge increased. High $\tau^{*}$ locations showed large lateral expansions as $Q$ increases within the bankfull channel. Areas high $\tau^{*}$ exhibited longitudinal extension, but magnitude in these areas were mediated because of divergent flow and lateral expansion. While these topographic features constricted the flow at $Q<Q_{\mathrm{bkf}}$, they allowed rapid extension of the effective flow area, dissipating the high $\tau^{*}$ that would have been expected as $Q$ increases. The shifts from lateral flow convergence to divergence change the core of high velocities from the channel centre as flow increases thereby dissipating the energy and decreasing hydraulic forces of the flow acting in the channel.

The lack of variation in channel width and bed geometry in the urban channel resulted in reduced variation in the spatial location of high $\tau^{*}$ as flow increased, with areas simply extending longitudinally and laterally. The relatively incised channel (compared to the nonurban site) with steep bank constricted the flow in the channel as $Q$ increased maintaining high $\tau^{*}$.

\subsection{SSWH availability}

\subsubsection{SSWH changes with discharges}


The total SSWH patch areas were different for the two study sites, given their morphological differences, but the changes with $Q$ showed a similar trend. In general, SSWH patch area was high at low $Q$ (Figure 7a) at $\sim 0.1-0.2 \mathrm{x} Q_{\mathrm{bkf}}$ at both sites. At the urban site, as the predominantly plane bed was inundated to greater depths at higher $Q$, velocity increased and a general decline in the SSWH area was observed. However, following a brief decline in SSWH below $Q_{\text {bkf }}$ the SSWH area in the non-urban site steadily increased as $Q$ approaches $Q_{\mathrm{bkf}}$ and rapidly increased as the floodplain was inundated for $Q>Q_{\mathrm{bkf}}$. This is supported by the gradually changing topographic relief extending from the thalweg to the floodplain. Planform complexity allows the inundation of new areas of lateral bars and benches, thus creating more SSWH. At low $Q$, the maximum SSWH patch area varied from 55 to 84 $\mathrm{m}^{2} / 100 \mathrm{~m}$ and 96 to $104 \mathrm{~m}^{2} / 100 \mathrm{~m}$ of the wetted area for the non-urban site and the urban site respectively.

The mean SSWH patch size follows a similar pattern as the total area of SSWH (Figure 7b). The SSWH patch size decreased ( 2 times) rapidly at the urban site with increasing $Q$, particularly as $Q$ approached $Q_{\mathrm{bkf}}$ compared to the non-urban site. Patch density consistently increased with $Q$ in the non-urban channel compared to the urban channel, where it decreased as $Q$ approached $Q_{\text {bkf }}$ (Figure 7c).

Within-year availability of the total SSWH patch area during the study period (Figure 8) revealed a considerable decline of SSWH availability in the urban site at high $Q$ during the winter period (June to September). In this period, the mean total area of SSWH patch was $\sim 35 \%$ greater in the non-urban site than the urban site. In contrast, the summer low flow periods (December to March) showed a higher SSWH patch area in the urban site. During the periods of $Q>Q_{\mathrm{bkf}}$, the percentage of the floodplain area acting as SSWH in the non-urban site was 2-4 times higher than the urban site.

\subsubsection{The spatial distribution of SSWH}

The SSWH occurred predominantly along the channel margins, expanding into the main channel in both study sites at low flows (Figure 9). The patches shifted further to the channel margins with increasing $Q$, but remained in large cohesive-linear patches in the non-urban 
channel compared to the contracted and fragmented patches in the urban. SSWH patches in the urban channel became more fragmented at higher $Q$ compared to those at the non-urban site.

The broad, low topographic relief of the adjacent banks at the non-urban site facilitated a greater spatial increase in SSWH patch area. This channel geometry allows more surface to be inundated with shallow depths by lateral overflow with increase in $Q$. With $Q>Q_{\text {bkf }}$, there is an increase in the spatial extent at which the floodplain is inundated at the non-urban site compared to the urban site thus increasing the availability of the SSWH areas. The locations of SSWH patches in the urban channel generally persisted, but patch area decreased with increasing $Q$. On the contrary, SSWH locations in the non-urban channel migrated and expanded or contracted with $Q$, reflecting the topographic dynamism of the stream channel at this site.

\subsection{Floodplain inundation}

For the same flow exceedances, much less of the urban floodplain is inundated at the urban site (Figure 10,11). At $Q_{\mathrm{bkf}}$, only $1 \%$ of the urban site floodplain area was inundated compared to the $6 \%$ at the non-urban site. At $Q>Q_{\mathrm{bkf}}$, much of the non-urban site floodplain was inundated compared to the urban-site. At these $Q$, the area extent of floodplain inundation was $\sim 5$ times larger than at the urban site.

Portions of the non-urban channel banks were overtopped for flows corresponding to $10-15$ $\%$ of time $Q$ exceeded ( $Q<Q_{\mathrm{bkf}}$ ). This appeared to be at low relief lateral portions of the nonurban channel. The estimated frequency (days/year) of urban floodplain inundation over the study period was estimated to be $\sim 45 \%$ lower than the non-urban site. Furthermore, predicted inundation duration was $\sim 3$ times higher at the non-urban site due to the longer cumulative duration of peak events $\left(Q>Q_{\mathrm{bkf}}\right)$ compared to the flashiness at the urban site.

\section{DISCUSSION}

\subsection{Urbanization impacts on stream hydraulic conditions.}


Despite the geographic proximity of both sites investigated in this study, the influence of urban stormwater inputs between the sites fundamentally alters hydraulic conditions. In this section we discuss the three main findings from this study, and highlight the opportunities for better understanding hydraulic alteration to improve the management of streams impacted by excess urban stormwater runoff.

\subsubsection{Influence on benthic disturbance}

Local variations in bed shear stress acting on benthos influence sediment entrainment and transport, which in turn drive the evolution of channel morphology. Changes in local flow dynamics govern bed mobility from zones of higher to lower bed mobility (Lisle et al., 2000; MacWilliams et al., 2006). The results indicate that the non-urban site would likely experience substantially lower bed shear stress. In contrast, areas of the streambed retaining low bed shear stress are limited in the urban site across the range of simulated discharges, consistent with the view that benthic area available as refugia is rapidly diminished in urban or modified aquatic systems whenever a flow event or spate occurs (Negishi et al., 2002; Finstad et al., 2007). The comparatively confined, straight and relatively uniform gradient and cross-sectional profile at the urban site account for the resultant rise in areas of potential bed entrainment as $Q$ increases, and thus loss of flow refugia.

It is widely recognised that the impact of altered flow on urban stream channel form eliminates important morphological features (such as meanders, bars and benches, riffle-pool sequences) (Chin, 2006; Vietz et al., 2014), thus decreasing channel variability. As shown in the non-urban site (Figure 6), at the stream-reach scale, channel morphological heterogeneity steers flow in such a way that the different topographic features turn on and off to create diverse patterns of hydraulic conditions as $Q$ increases (Strom et al., 2016). This suggests that morphological heterogeneity will decrease areas of streambed that are subjected to high hydraulic stress with rising flows. Consequently, benthic species assemblages in natural hydraulically complex stream reaches are more persistent than in simple, modified ones (Negishi et al., 2002; Vericat et al., 2008). 
The area of channel experiencing likely bed entrainment rises rapidly for $Q$ between 0.3 0.9x $Q_{\mathrm{bkf}}$ (Figure 4), suggesting that management efforts to reduce bed disturbance should target these flows for control by flow-regime restoration practices.

In this study, the frequency and duration of likely bed particle entrainment at the urban site was substantially higher than for the non-urban site. The estimated daily peak shear stress equalled or exceeded the critical shear stress for 120 days/year for the urban site, compared to 35 days/year in the non-urban site. This coincides with the hydrological observation of Wong et al. (2000), who report that urban streams in Melbourne are typically disturbed by impervious runoff more than 100 times/year. Local patch-scale benthic disturbance occurs even for relatively small changes to $Q$. Vericat et al. (2008) reported that patches of sandgravel bed may attain partial or full entrainment even during smaller but more frequent flow events.

The geomorphic and thus ecological consequence of the modeled bed shear stress regime is expected to be large, given that it will cause frequent entrainment of surface sediments and eventually, mobilize subsurface particles. This activity can regularly adjust the physical habitat (Francoeur \& Biggs, 2006). A longer period of high bed shear stress combined with a lack of peripheral SSWH will reduce the chance of benthic invertebrates finding refugia (Lancaster et al., 2006; Oldmeadow et al., 2010). Removal of bed sediments is also the precursor to channel incision (Hawley et al., 2012). This is consistent with studies hypothesising that streams in urban catchments having a percentage connected impervious surface above $1 \%$ experience bed movement, major incision and loss of sensitive biota resulting in decreased ecological quality (Walsh et al., 2005a; Vietz et al., 2014). However, the magnitude of this phenomenon could also depend on the sediment supply (Chin, 2006).

The findings here also suggest that considerable hydraulic alterations are expected even at the low level of connected imperviousness ( $3 \%$ at the urban site), confirming the dominant role of excess urban stormwater runoff in influencing hydraulic alteration. Vietz et al. (2014) similarly reported large geomorphic changes in urban streams at very low levels of connected imperviousness $(<2-3 \%)$. 


\subsubsection{Impacts on shallow slow-water habitat}

The channel geometry in the non-urban site ensures a gentler increase in depth laterally and longitudinally, as $Q$ increases. The channel wetted area increases without significant increases in flow depth and velocity particularly towards channel margins. Thus, as $Q$ increase, more surface area is inundated with shallow depth and low velocity, increasing the SSWH area. Conversely, the predominantly straight, uniform, plane-bed, U-shaped channel at the urban site means there is less variability in flow depth and a steeper increase in depth and velocity with increasing $Q$. Thus, as $Q$ increases, the SSWH area decreases.

The SSWH and $Q$ relationship observed for the urban and non-urban site can be compared to the conceptual model defined by Vietz et al. (2013). For complex channels (with higher bars and extensive shoals), as observed at the non-urban site in this study, the SSWH areas increase as the high-level bars and extended shoals are inundated. Nevertheless, the rate of increase may fall depending on the flow velocities over these features with increased flow depth (Knighton, 1974; Stewardson, 2005). For modified or simple channels (with nearvertical banks), as observed at the urban site, rapid declines of SSWH area is expected, even at comparatively low $Q$.

For the urban site, rapid declines in patch size ( 2 times of SSWH patch size) were observed for relatively small increases in $Q$ compared to the non-urban site. This is expected to impact species assemblages as the smaller the individual SSWH patches, the less chance species have to survive progressive downstream drift (Vietz et al., 2013). In addition, the SSWH patches in the urban site become more fragmented as $Q$ increases. Reducing contiguousness of SSWH patches lessens their ecological value (Dodd, 1990; Collinge, 1996), thus impacting ecological diversity (Collinge, 1996; Ewers \& Didham, 2006).

SSWH patches locations in the urban site were comparatively static, occurring at discrete zones even as $Q$ increased. In contrast, morphological heterogeneity at the non-urban channel allowed large SSWH patches to be separated and distributed into many small units. Such diminishing spatial heterogeneity in the urban site could contribute to species segregation and declines in abundance and diversity (Collinge, 1996). 
Habitat availability in the urban site clearly suggest that the modified channel together with altered flow regime driven by urban impacts may provide limited SSWH habitat. In urban catchments where streams experience increased frequency of peak flows (Burns et al., 2012; Walsh et al., 2012), the decreased availability of SSWH can persist for long periods, reducing rearing and breeding habitat and refuge. This could be a key contributing factor for local extinction and declined diversity and abundance of biota (Diamond \& Serveiss, 2001; Poznańska et al., 2009; Wenger et al., 2009; Koperski, 2010). Aquatic systems with an abundance of available SSWH are usually able to more effectively support diverse aquatic life populations (West \& Jones, 2001; Poznańska et al., 2009).

\subsubsection{Impacts on floodplain inundation}

The assessment of the inundation extent suggests a substantial impact of urbanization on the floodplain inundation. The results on the estimated relative differences in the floodplain inundation area at both sites reveals two general points. First, compared to the non-urban site, our analysis shows that the frequency of floodplain inundation in the urban site is likely to decrease. While altered catchment hydrology increases the magnitude and frequency of higher discharge events (Figure 2), the increased channel capacity at the urban site would require a very high, non-frequently occurring discharge to overtop the banks. This means the reach will experience low rates of increase in inundation per unit flow, and consequently, a high reduction in the inundated floodplain area. In addition, the duration of inundation is expected to be reduced compared to non-urban analogues given the flashiness of high flows (Walsh et al., 2012). Likewise, typically, confined incised stream reaches have limited floodplain space often restricted by valley walls (e.g., Grant \& Swanson, 1995; Vietz et al., 2015) as the case of the urban site. While this geomorphic control limits the extent to which inundation can occur, it also reduces the duration of the inundation (Cienciala \& Pasternack, 2017).

We hypothesize that for urban streams with major changes to the flow regime and channel form, the expected changes to the pattern (frequency and duration) of inundation will mean altered lateral hydrologic connections between the stream and its floodplain. This could alter 
seasonal timing and variability in the inundation pulse, potentially affecting the ability of floodplain biota to cope with and gain from inundation (Kingsford, 2000; Hamilton et al., 2002).

\subsection{Implications of hydraulics for ecosystem processes and restoration strategies in urban} streams

The protection or restoration of urban streams requires understanding of the relationship between catchment urbanization (particularly stormwater impacts) and a stream's physical and biological process responses (Wenger et al., 2009). Figure 12 depicts a conceptual framework of how individual stressors interact to impact the stream ecosystem. Hydraulic conditions are the mediator between exogenous drivers (such as hydrology and morphology) and ecological responses.

Until recently, altered channel morphology (Chin \& Gregory, 2009; Vietz et al., 2016) and hydrology (Wenger et al., 2009; Walsh et al., 2012) have been considered as the major determinants of observed changes in stream physical and biological structure and function. Management strategies to protect or restore urban streams typically involve either enhancing the channel morphology, creating specific habitat characteristics to achieve perceived "better" habitat conditions (Bernhardt \& Palmer, 2011), or catchment-scale practices that aim to restore flow regimes towards their pre-development levels. However, achieving ecologically successful restoration still remains a struggle, in particular because morphological adjustments usually do not address the underlying mechanisms of disturbance (Bernhardt \& Palmer, 2011; Violin et al., 2011). While flow-regime restoration efforts are more likely to do so, returning to near natural levels can be very difficult (Duncan et al., 2014; Fletcher et al., 2014).

As demonstrated in this study, urban-induced altered hydrology and morphology have substantial impacts on the stream hydraulic conditions. This potentially becomes a key agent of declined ecological health usually observed in urban streams including declined diversity and abundance of biota (Wenger et al., 2009). This means management efforts towards protection and restoration of urban streams should incorporate objectives of achieving 
ecologically relevant hydraulic conditions that would sustain the stream ecosystem health. Indeed, it is well established that stream communities and many ecosystem functions depend on hydraulic behaviour (Statzner et al., 1988; Gibbins et al., 2007; Clark et al., 2008; Knight \& Cuffney, 2012). Our findings suggest that stream hydraulic condition metrics can be assessed by stream managers in their efforts to understand the mechanisms driving urban stream degradation. They may be used to simulate and evaluate geomorphically and ecologically important flow patterns within urban streams, to guide targeted restoration efforts both at the catchment scale and within the channel (Pasternack \& Brown, 2013; Brown et al., 2016).

Ultimately, it is necessary to set objectives that are directly linked to the needs of the receiving stream. Given the need that managed flows and channel morphology should result in sustainable geomorphic functioning (i.e. appropriate levels of erosion and deposition), and suitable hydraulic habitat conditions for biotic functioning, building management standards based on the hydraulic outcomes is a prerequisite to protecting the channel and restoring stream ecosystems (Pasternack, 2008).

\section{CONCLUSIONS}

Altered stream hydrology driven by urban stormwater runoff is a key stressor to urban stream ecosystems. In this study, we investigated and demonstrated the hydraulic response to flow in an urban and non-urban stream, using 2D model simulations and three metrics that addressed bed disturbance, SSWH, and floodplain inundation. The urban stream was found to have a substantially altered hydraulic regime. Bed disturbance was nearly always greater in the urban channel and approximately four times higher as flow increased, while SSWH availability in the urban stream was greatly diminished. The areal extent of floodplain inundation in the urban stream was limited to flood flows (i.e. rare events), indicating likely extended periods of lateral disconnections between the stream and its floodplain.

The results highlight the important interplay between hydrology, geomorphology, and hydraulics in dynamically evolving the discharge-hydraulic conditions in stream channels. In urban streams considering either just hydrology, or just channel morphology, in isolation, 
may not adequately achieve ecologically successful restoration. Restoration efforts should include technical objectives to restore a natural hydraulic regime as part of a multi-scalar approach that considers local, segment, and catchment scale concerns. Implementing such hydraulic-based approaches will be helpful in prioritizing and integrating management efforts between mitigation of hydrology and channel morphology interventions to achieve restoration targets.

\section{ACKNOWLEDGMENTS}

This work was funded by University of Melbourne Research Scholarship and the Melbourne Waterway Research Practice Partnership, supported by Melbourne Water. We thank the following staff of the Waterway Ecosystem Research Group of University of Melbourne who assisted with field work: Peter Poelsma, Robert James, Michael Sammonds, Mathieu Bachaud and Andrew Thomas. This paper benefited greatly from comments by Jason Wiener. T. Fletcher was supported by ARC project FT100100144 during part of this work.

\section{REFERENCES}

Acreman, M., \& Dunbar, M. J. (2004). Defining environmental river flow requirements? A review. Hydrology and Earth System Sciences Discussions, 8(5), 861-876.

Bernhardt, E. S., \& Palmer, M. A. (2011). River restoration: the fuzzy logic of repairing reaches to reverse catchment scale degradation. Ecological Applications, 21(6), 19261931.

Bledsoe, B. P., \& Watson, C. C. (2001). Effects of urbanization on channel instability. JAWRA Journal of the American Water Resources Association, 37(2), 255-270.

Brabec, E., Schulte, S., \& Richards, P. L. (2002). Impervious surfaces and water quality: a review of current literature and its implications for watershed planning. Journal of planning literature, 16(4), 499-514.

Brooks, A. J., Haeusler, T., Reinfelds, I., \& Williams, S. (2005). Hydraulic microhabitats and the distribution of macroinvertebrate assemblages in riffles. Freshwater biology, $50(2), 331-344$.

This article is protected by copyright. All rights reserved. 
Brown, R. A., Pasternack, G. B., \& Lin, T. (2016). The topographic design of river channels for form-process linkages. Environmental management, 57(4), 929-942.

Buffington, J. M., \& Montgomery, D. R. (1997). A systematic analysis of eight decades of incipient motion studies, with special reference to gravel-bedded rivers. Water Resources Research, 33(8), 1993-2029.

Burns, M. J., Fletcher, T. D., Walsh, C. J., Ladson, A. R., \& Hatt, B. E. (2012). Hydrologic shortcomings of conventional urban stormwater management and opportunities for reform. Landscape and Urban Planning, 105(3), 230-240.

Chin, A. (2006). Urban transformation of river landscapes in a global context. Geomorphology, 79(3), 460-487.

Chin, A., \& Gregory, K. (2009). From research to application: management implications from studies of urban river channel adjustment. Geography Compass, 3(1), 297-328.

Cienciala, P., \& Pasternack, G. (2017). Floodplain inundation response to climate, valley form, and flow regulation on a gravel-bed river in a Mediterranean-climate region. Geomorphology, 282, 1-17.

Clark, J. S., Rizzo, D. M., Watzin, M. C., \& Hession, W. C. (2008). Spatial distribution and geomorphic condition of fish habitat in streams: an analysis using hydraulic modelling and geostatistics. River Research and Applications, 24(7), 885-899.

Collinge, S. K. (1996). Ecological consequences of habitat fragmentation: implications for landscape architecture and planning. Landscape and Urban Planning, 36(1), 59-77.

Diamond, J. M., \& Serveiss, V. B. (2001). Identifying sources of stress to native aquatic fauna using a watershed ecological risk assessment framework: ACS Publications.

Dodd, C. K. (1990). Effects of habitat fragmentation on a stream-dwelling species, the flattened musk turtle Sternotherus depressus. Biological Conservation, 54(1), 33-45.

Duncan, H. P., Fletcher, T. D., Vietz, G., \& Urrutiaguer, M. (2014). The feasibility of maintaining ecologically and geomorphically important elements of the natural flow regime in the context of a superabundance of flow. Melbourne Waterway ResearchPractice Partnership Technical Report, 14(5). 
Escobar-Arias, M., \& Pasternack, G. B. (2010). A hydrogeomorphic dynamics approach to assess in-stream ecological functionality using the functional flows model, part 1model characteristics. River Research and Applications, 26(9), 1103-1128.

Ewers, R. M., \& Didham, R. K. (2006). Confounding factors in the detection of species responses to habitat fragmentation. Biological reviews, 81(1), 117-142.

Finstad, A., Einum, S., Forseth, T., \& Ugedal, O. (2007). Shelter availability affects behaviour, size-dependent and mean growth of juvenile Atlantic salmon. Freshwater biology, 52(9), 1710-1718.

Fletcher, T. D., Vietz, G., \& Walsh, C. J. (2014). Protection of stream ecosystems from urban stormwater runoff The multiple benefits of an ecohydrological approach. Progress in Physical Geography, 0309133314537671.

Francoeur, S. N., \& Biggs, B. J. (2006). Short-term effects of elevated velocity and sediment abrasion on benthic algal communities Advances in Algal Biology: A Commemoration of the Work of Rex Lowe (pp. 59-69): Springer.

Gibbins, C., Vericat, D., \& Batalla, R. J. (2007). When is stream invertebrate drift catastrophic? The role of hydraulics and sediment transport in initiating drift during flood events. Freshwater biology, 52(12), 2369-2384.

Gorski, K., De Leeuw, J. J., Winter, H. V., Vekhov, D. A., Minin, A. E., Buijse, A. D., \& Nagelkerke, L. A. (2011). Fish recruitment in a large, temperate floodplain: the importance of annual flooding, temperature and habitat complexity. Freshwater biology, 56(11), 2210-2225.

Grant, G., \& Swanson, F. (1995). Morphology and processes of valley floors in mountain streams, western Cascades, Oregon. Natural and anthropogenic influences in fluvial geomorphology, 83-101.

Hamilton, S. K., Sippel, S. J., \& Melack, J. M. (2002). Comparison of inundation patterns among major South American floodplains. Journal of Geophysical Research: Atmospheres, 107(D20).

This article is protected by copyright. All rights reserved. 
Hawley, R. J., \& Bledsoe, B. P. (2011). How do flow peaks and durations change in suburbanizing semi-arid watersheds? A southern California case study. Journal of Hydrology, 405(1), 69-82.

Hawley, R. J., Bledsoe, B. P., Stein, E. D., \& Haines, B. E. (2012). Channel Evolution Model of Semiarid Stream Response to Urban-Induced Hydromodification1. JAWRA Journal of the American Water Resources Association, 48(4), 722-744.

Humphries, P., Cook, R. A., Richardson, A. J., \& Serafini, L. G. (2006). Creating a disturbance: manipulating slackwaters in a lowland river. River Research and Applications, 22(5), 525-542.

Jorde, K., \& Bratrich, C. (1998). River bed morphology and flow regulations in diverted streams: effects on bottom shear stress patterns and hydraulic habitat. Advances in River Bottom Ecology., 47-63.

Jowett, I. (2003). Hydraulic constraints on habitat suitability for benthic invertebrates in gravel-bed rivers. River Research and Applications, 19(5-6), 495-507.

Kemp, J. L., Harper, D. M., \& Crosa, G. A. (2000). The habitat-scale ecohydraulics of rivers. Ecological Engineering, 16(1), 17-29.

King, A., Humphries, P., \& Lake, P. (2003). Fish recruitment on floodplains: the roles of patterns of flooding and life history characteristics. Canadian Journal of Fisheries and Aquatic Sciences, 60(7), 773-786.

King, R. S., Baker, M. E., Kazyak, P. F., \& Weller, D. E. (2011). How novel is too novel? Stream community thresholds at exceptionally low levels of catchment urbanization. Ecological Applications, 21(5), 1659-1678.

Kingsford, R. T. (2000). Ecological impacts of dams, water diversions and river management on floodplain wetlands in Australia. Austral Ecology, 25(2), 109-127.

Knight, R. R., \& Cuffney, T. F. (2012). Invertebrate response to changes in streamflow hydraulics in two urban areas in the United States: US Geological Survey.

Knighton, A. D. (1974). Variation in width-discharge relation and some implications for hydraulic geometry. Geological Society of America Bulletin, 85(7), 1069-1076. 
Koperski, P. (2010). Urban environments as habitats for rare aquatic species: The case of leeches (Euhirudinea, Clitellata) in Warsaw freshwaters. Limnologica-Ecology and Management of Inland Waters, 40(3), 233-240.

Ladson, A. R., Walsh, C. J., \& Fletcher, T. D. (2006). Improving stream health in urban areas by reducing runoff frequency from impervious surfaces. Australian Journal of Water Resources, 10(1), 23-33.

Lancaster, J., BUFFIN-BÉLANGER, T., Reid, I., \& Rice, S. (2006). Flow-and substratummediated movement by a stream insect. Freshwater biology, 51(6), 1053-1069.

Lisle, T. E., Nelson, J. M., Pitlick, J., Madej, M. A., \& Barkett, B. L. (2000). Variability of bed mobility in natural, gravel-bed channels and adjustments to sediment load at local and reach scales. Water Resources Research, 36(12), 3743-3755.

Lobera, G., Muñoz, I., López-Tarazón, J., Vericat, D., \& Batalla, R. (2017). Effects of flow regulation on river bed dynamics and invertebrate communities in a Mediterranean river. Hydrobiologia, 784(1), 283-304.

MacWilliams, M. L., Wheaton, J. M., Pasternack, G. B., Street, R. L., \& Kitanidis, P. K. (2006). Flow convergence routing hypothesis for pool-riffle maintenance in alluvial rivers. Water Resources Research, 42(10).

McCabe, D. J., \& Gotelli, N. J. (2000). Effects of disturbance frequency, intensity, and area on assemblages of stream macroinvertebrates. Oecologia, 124(2), 270-279.

McGarigal, K., \& Marks, B. J. (1995). FRAGSTATS: spatial pattern analysis program for quantifying landscape structure.

Mérigoux, S., \& Dolédec, S. (2004). Hydraulic requirements of stream communities: a case study on invertebrates. Freshwater biology, 49(5), 600-613.

Meyer, J. L., Paul, M. J., \& Taulbee, W. K. (2005). Stream ecosystem function in urbanizing landscapes. Journal of the North American Benthological Society, 24(3), 602-612.

Milhous, R. T., \& Nestler, J. (2016). On history of habitat criteria in instream flow studies. Part I. Paper presented at the 11th International Symposium on Ecohydraulics (ISE 2016).

This article is protected by copyright. All rights reserved. 
Morley, S. A., \& Karr, J. R. (2002). Assessing and restoring the health of urban streams in the Puget Sound basin. Conservation biology, 16(6), 1498-1509.

Negishi, J., Inoue, M., \& Nunokawa, M. (2002). Effects of channelisation on stream habitat in relation to a spate and flow refugia for macroinvertebrates in northern Japan. Freshwater biology, 47(8), 1515-1529.

Oldmeadow, D. F., Lancaster, J., \& Rice, S. P. (2010). Drift and settlement of stream insects in a complex hydraulic environment. Freshwater biology, 55(5), 1020-1035.

Pasternack, G. B. (2008). Spawning habitat rehabilitation: advances in analysis tools. Paper presented at the American Fisheries Society Symposium.

Pasternack, G. B. (2011). 2D modeling and ecohydraulic analysis: University of California at Davis.

Pasternack, G. B., \& Brown, R. A. (2013). Ecohydraulic Design of Riffle-Pool Relief and Morphological Unit Geometry in Support of Regulated Gravel-Bed River Rehabilitation. Ecohydraulics: An Integrated Approach, 337-355.

Paterson, A., \& Whitfield, A. (2000). Do shallow-water habitats function as refugia for juvenile fishes? Estuarine, Coastal and Shelf Science, 51(3), 359-364.

Paul, M., \& Meyer, J. (2008). Streams in the Urban Landscape. In J. Marzluff, E. Shulenberger, W. Endlicher, M. Alberti, G. Bradley, C. Ryan, U. Simon \& C. ZumBrunnen (Eds.), Urban Ecology (pp. 207-231): Springer US.

Poznańska, M., Kobak, J., Wolnomiejski, N., \& Kakareko, T. (2009). Shallow-water benthic macroinvertebrate community of the limnic part of a lowland Polish dam reservoir. Limnologica-Ecology and Management of Inland Waters, 39(2), 163-176.

Reinfelds, I., Cohen, T., Batten, P., \& Brierley, G. (2004). Assessment of downstream trends in channel gradient, total and specific stream power: a GIS approach. Geomorphology, 60(3), 403-416.

Roy, A. H., Freeman, M. C., Freeman, B. J., Wenger, S. J., Ensign, W. E., \& Meyer, J. L. (2005). Investigating hydrologic alteration as a mechanism of fish assemblage shifts in urbanizing streams. Journal of the North American Benthological Society, 24(3), 656-678.

This article is protected by copyright. All rights reserved. 
Shearer, K., Hayes, J., Jowett, I., \& Olsen, D. (2015). Habitat suitability curves for benthic macroinvertebrates from a small New Zealand river. New Zealand journal of marine and freshwater research, 49(2), 178-191.

Statzner, B., Gore, J. A., \& Resh, V. H. (1988). Hydraulic Stream Ecology: Observed Patterns and Potential Applications. Journal of the North American Benthological Society, 7(4), 307-360. doi: 10.2307/1467296

Statzner, B., \& Higler, B. (1986). Stream hydraulics as a major determinant of benthic invertebrate zonation patterns. Freshwater biology, 16(1), 127-139.

Steuer, J. J., Bales, J. D., \& Giddings, E. M. P. (2009). Relationship of stream ecological conditions to simulated hydraulic metrics across a gradient of basin urbanization. Journal of the North American Benthological Society, 28(4), 955-976. doi: dx.doi.org/10.1899/08-157.1

Stewardson, M. (2005). Hydraulic geometry of stream reaches. Journal of Hydrology, 306(14), 97-111. doi: http://dx.doi.org/10.1016/j.jhydrol.2004.09.004

Strom, M. A., Pasternack, G. B., \& Wyrick, J. R. (2016). Reenvisioning velocity reversal as a diversity of hydraulic patch behaviours. Hydrological Processes, 30(13), 2348-2365.

Syme, W. (2001). TUFLOW-Two \& Onedimensional unsteady flow Software for rivers, estuaries and coastal waters. Paper presented at the IEAust Water Panel Seminar and Workshop on 2d Flood Modelling, Sydney.

Turner, M., \& Stewardson, M. (2014). Hydrologic indicators of hydraulic conditions that drive flow-biota relationships. Hydrological Sciences Journal, 59(3-4), 659-672.

Vericat, D., Batalla, R. J., \& Gibbins, C. N. (2008). Sediment entrainment and depletion from patches of fine material in a gravel-bed river. Water Resources Research, 44(11).

Vietz, G. J., Rutherfurd, I. D., Fletcher, T. D., \& Walsh, C. J. (2016). Thinking outside the channel: Challenges and opportunities for protection and restoration of stream morphology in urbanizing catchments. Landscape and Urban Planning, 145, 34-44.

Vietz, G. J., Sammonds, M. J., \& Stewardson, M. J. (2013). Impacts of flow regulation on slackwaters in river channels. Water Resources Research, 49(4), 1797-1811.

This article is protected by copyright. All rights reserved. 
Vietz, G. J., Sammonds, M. J., Walsh, C. J., Fletcher, T. D., Rutherfurd, I. D., \& Stewardson, M. J. (2014). Ecologically relevant geomorphic attributes of streams are impaired by even low levels of watershed effective imperviousness. Geomorphology, 206, 67-78.

Vietz, G. J., Walsh, C. J., \& Fletcher, T. D. (2015). Urban hydrogeomorphology and the urban stream syndrome Treating the symptoms and causes of geomorphic change. Progress in Physical Geography, 40(3), 480-492.

Violin, C. R., Cada, P., Sudduth, E. B., Hassett, B. A., Penrose, D. L., \& Bernhardt, E. S. (2011). Effects of urbanization and urban stream restoration on the physical and biological structure of stream ecosystems. Ecological Applications, 21(6), 1932-1949. doi: $10.2307 / 41416629$

Walsh, C. J. (2004). Protection of in-stream biota from urban impacts: minimise catchment imperviousness or improve drainage design? Marine and Freshwater Research, 55(3), 317-326.

Walsh, C. J., Fletcher, T. D., \& Burns, M. J. (2012). Urban stormwater runoff: a new class of environmental flow problem.

Walsh, C. J., Fletcher, T. D., \& Ladson, A. R. (2005a). Stream restoration in urban catchments through redesigning stormwater systems: looking to the catchment to save the stream. Journal of the North American Benthological Society, 24(3), 690-705.

Walsh, C. J., Roy, A. H., Feminella, J. W., Cottingham, P. D., Groffman, P. M., \& Morgan II, R. P. (2005b). The urban stream syndrome: current knowledge and the search for a cure. Journal of the North American Benthological Society, 24(3), 706-723.

Walsh, C. J., Roy, A. H., Feminella, J. W., Cottingham, P. D., Groffman, P. M., \& Morgan, R. P. (2005c). The urban stream syndrome: current knowledge and the search for a cure. Journal of the North American Benthological Society, 24(3), 706-723. doi: Doi $10.1899 / 04-020.1$

Wenger, S. J., Roy, A. H., Jackson, C. R., Bernhardt, E. S., Carter, T. L., Filoso, S., . . . Martí, E. (2009). Twenty-six key research questions in urban stream ecology: an assessment of the state of the science. Journal of the North American Benthological Society, 28(4), 1080-1098.

This article is protected by copyright. All rights reserved. 
West, R. J., \& Jones, M. (2001). Shallow Water Fish Communities of New South Wales South Coast Estuaries: Fisheries Research and Development Corporation.

Wohl, E., Lane, S. N., \& Wilcox, A. C. (2015). The science and practice of river restoration. Water Resources Research, 51(8), 5974-5997.

Wolman, M. G. (1954). A method of sampling coarse river-bed material. EOS, Transactions American Geophysical Union, 35(6), 951-956.

Wong, T., Breen, P. F., \& Lloyd, S. D. (2000). Water sensitive road design: design options for improving stormwater quality of road runoff: CRC for Catchment Hydrology Melburne, Australia.

Yarnell, S. M., Petts, G. E., Schmidt, J. C., Whipple, A. A., Beller, E. E., Dahm, C. N., . . . Viers, J. H. (2015). Functional flows in modified riverscapes: hydrographs, habitats and opportunities. BioScience, 65(10), 963-972.

This article is protected by copyright. All rights reserved. 
Table 1. Characteristics of the two study sites

\begin{tabular}{|c|c|c|}
\hline & Urban site & Non-urban site \\
\hline Catchment area $\left(\mathrm{km}^{2}\right)$ & 67.3 & 43.5 \\
\hline Latitude, Longitude & $\begin{array}{l}38^{\circ} 03^{\prime} 02.34 \square \mathrm{S}, \\
145^{\circ} 21^{\prime} 53.42 \square \mathrm{E}\end{array}$ & $\begin{array}{l}38^{\circ} 0^{\prime} 38.35 \square \mathrm{S}, \\
145^{\circ} 23^{\prime} 1.32 \square \mathrm{E}\end{array}$ \\
\hline $\begin{array}{l}\text { Total imperviousness } \\
\text { surfaces }(\%)\end{array}$ & 7.1 & 4.3 \\
\hline $\begin{array}{c}\text { Connected imperviousness } \\
\text { surfaces }(\%)^{\mathrm{a}}\end{array}$ & 3.1 & 0.1 \\
\hline $\begin{array}{l}\text { Mean catchment rainfall } \\
(\mathrm{mm} / \text { year })^{\mathrm{b}}\end{array}$ & 969.6 & 969.6 \\
\hline Reach gradient $(\%)^{\mathrm{c}}$ & 0.003 & 0.001 \\
\hline Sinuosity $^{\mathrm{c}}$ & 1.1 & 1.3 \\
\hline Entrenchment ratio $^{c}$ & 1.2 & 1.9 \\
\hline Mean bankfull depth $(\mathrm{m})^{\mathrm{c}}$ & 1.6 & 0.84 \\
\hline Mean bankfull width $(\mathrm{m})^{\mathrm{c}}$ & 7.02 & 4.10 \\
\hline $\begin{array}{l}\text { Reach bankfull discharge } \\
\left(\mathrm{m}^{3} / \mathrm{s}\right)\end{array}$ & 1.72 & 0.73 \\
\hline $\begin{array}{l}\text { Reach median discharge } \\
\left(\mathrm{m}^{3} / \mathrm{s}\right)\end{array}$ & 0.39 & 0.21 \\
\hline $\begin{array}{l}\text { Reach baseflow discharge } \\
\left(\mathrm{m}^{3} / \mathrm{s}\right)\end{array}$ & 0.03 & 0.04 \\
\hline Sediment size $\left(\mathrm{D}_{50}\right)(\mathrm{mm})$ & 6 & 3 \\
\hline
\end{tabular}

${ }^{a}$ The percentage of total imperviousness surface directly connected to the stream

${ }^{b}$ Melbourne Water gauge - 586199 (356116.69E, 5791708.09N)

${ }^{\mathrm{c}}$ Estimates from topographic survey data 


\section{Figure Captions:}

Figure 1. Cardinia Shire catchment, the Cardinia creek and the locations of the (A) non-urban and (B) urban sites

Figure 2. (A) Stream flow hydrographs and (B) Flow duration curve for the urban and nonurban study sites during study period.

Figure 3. Plot of (A) Maximum (95th percentile) bed shear stress and (B) Average bed shear stress across selected discharges modelled for the urban and non-urban site. Dashed horizontal line and the arrows represents the estimated critical bed shear stress and bankfull discharge respectively.

Figure 4. Plots of proportion of channel wetted bed area under different Shields stress in nonurban and urban site as it relates to discharge. Black line represents portion of wetted areas of bed likely to be entrained with $\tau^{*}>0.06$ (Full) whereas deep grey line and light grey line are areas with $\tau^{*}$ between 0.03 and 0.06 (Intermittent) and $\tau^{*}<0.03$ (None) than representing intermittent and no entrainment bed areas respectively.

Figure 5. Time series of the daily maximum (95th percentile) bed shear stress for the urban and non-urban site for the period under investigation. Solid horizontal line represents the estimated critical bed shear stress.

Figure 6. 2D hydrodynamic modelling results of Shields stress pattern for selected flows, showing the mapped distribution of potential bed entrainment for both (A) non-urban and (B) urban reach. These are representative of the respective Baseflow, Median Q, Qbkf and 2x Qbkf of the flow regime at both sites. 
Figure 7. Relations between discharge and selected spatial metrics per $100 \mathrm{~m}$ of study reach for Shallow Slow Water habitat (SSWH): (A) Total SSWH patch area, (B) Mean SSWH patch size, (C) SSWH patch density for urban and non-urban site at selected discharges.

Figure 8. Time series of the daily total SSWH patch area available for the urban and nonurban site for the period under investigation. Horizontal dashes represent the floodplain level of total SSWH patch area for both non-urban (SSWH $\geq 120 \mathrm{~m} 2 / 100 \mathrm{~m})$ and urban (SSWH $\leq$ $45 \mathrm{~m} 2$ / 100m) respectively.

Figure 9. 2D mapped spatial distribution of the SSWH (red shading) for selected discharges in the non-urban (left maps) and urban (right maps) sites. These are representative of the respective Baseflow, Median Q, Qbkf and 2x Qbkf of the flow regime at both sites.

Figure 10. Relation between percentage of floodplain inundation area and selected stream flow duration.

Figure 11. 2D mapped extent of the floodplain inundation area (blue) for selected streamflow durations in the (A) non-urban and (B) urban sites.

Figure 12. Conceptual framework of urban impacts on a stream (adapted from Walsh et al., 2005b). All stream ecosystem variables are grouped in one entity (right) and the catchment variables (left). The arrows connecting the different entities shows hypothesized causal relationships and major pathways. While the sources of impact are numerous, the major pathway of changes is stormwater runoff from connected impervious surfaces introduced into the stream by pipes and drains. It also shows that hydraulics is the mediator between exogenous drivers and ecological responses. The direction of the expected effects are by + and - which indicates increasing and decreasing impact respectively. 


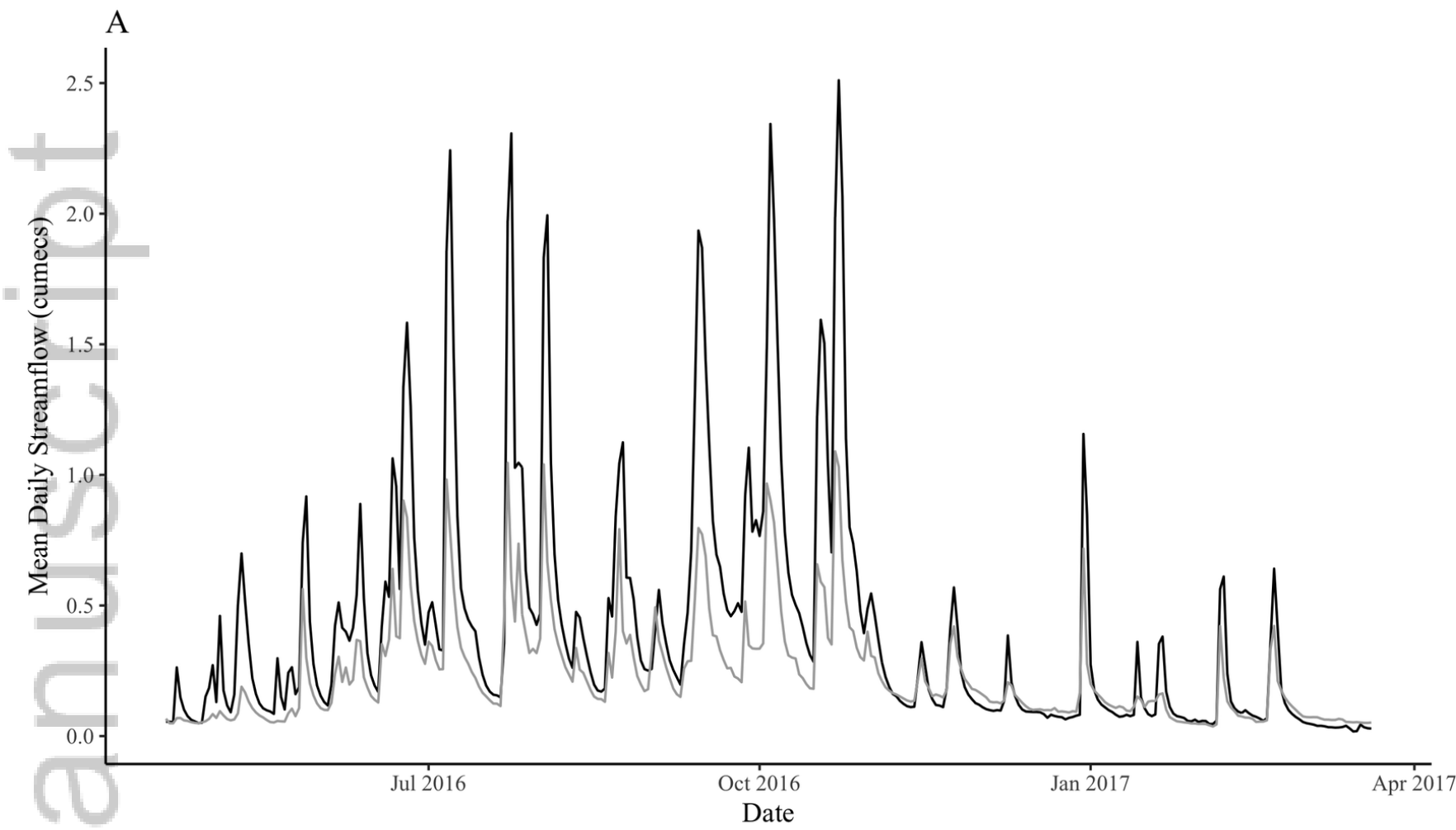

- Urban

- Non-Urban

\section{\begin{tabular}{l}
\hline \\
\hline \\
\hline \\
\hline \\
\hline
\end{tabular}

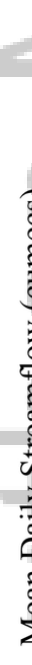

B

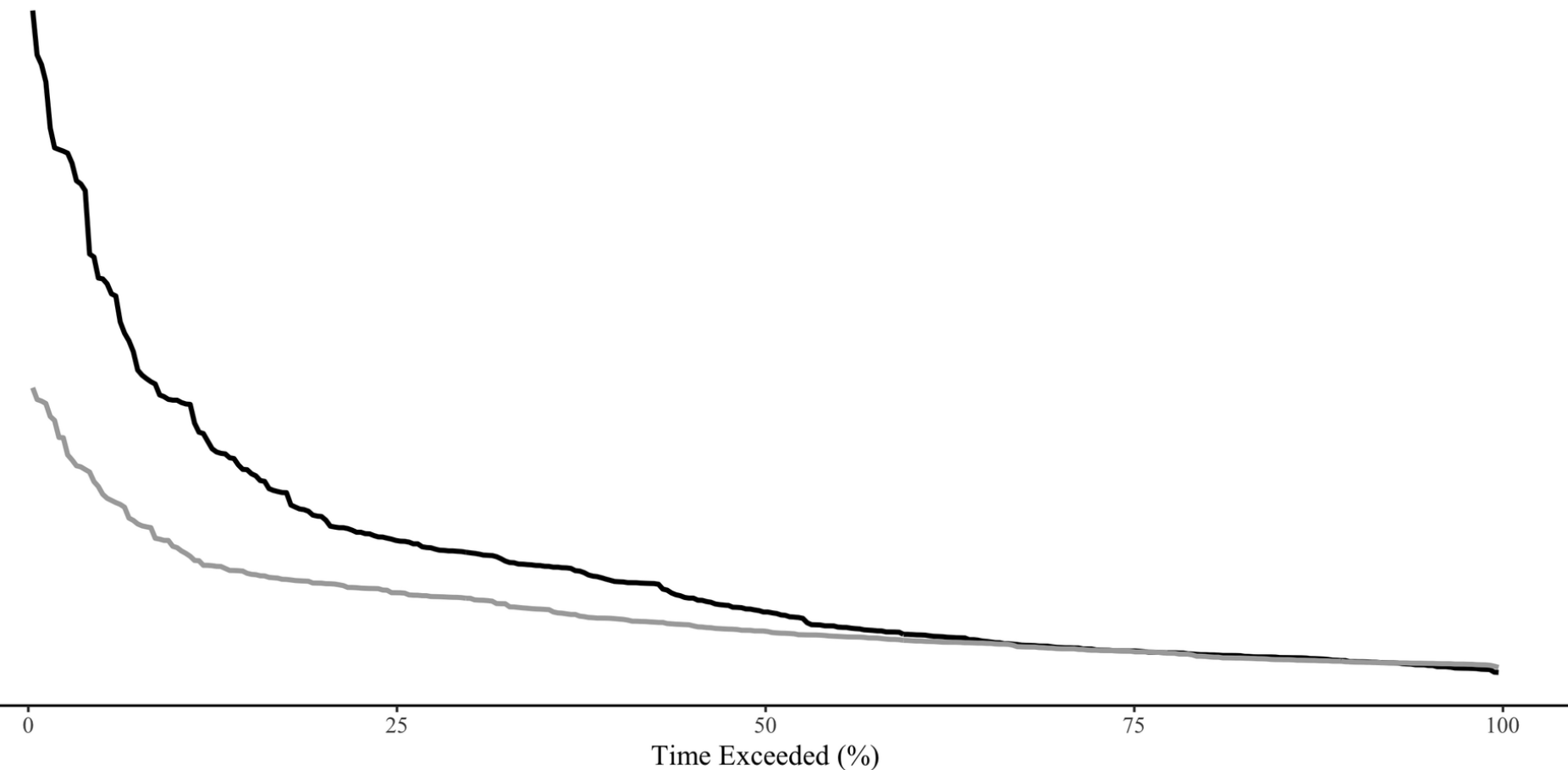

RRA_3293_f2.png 

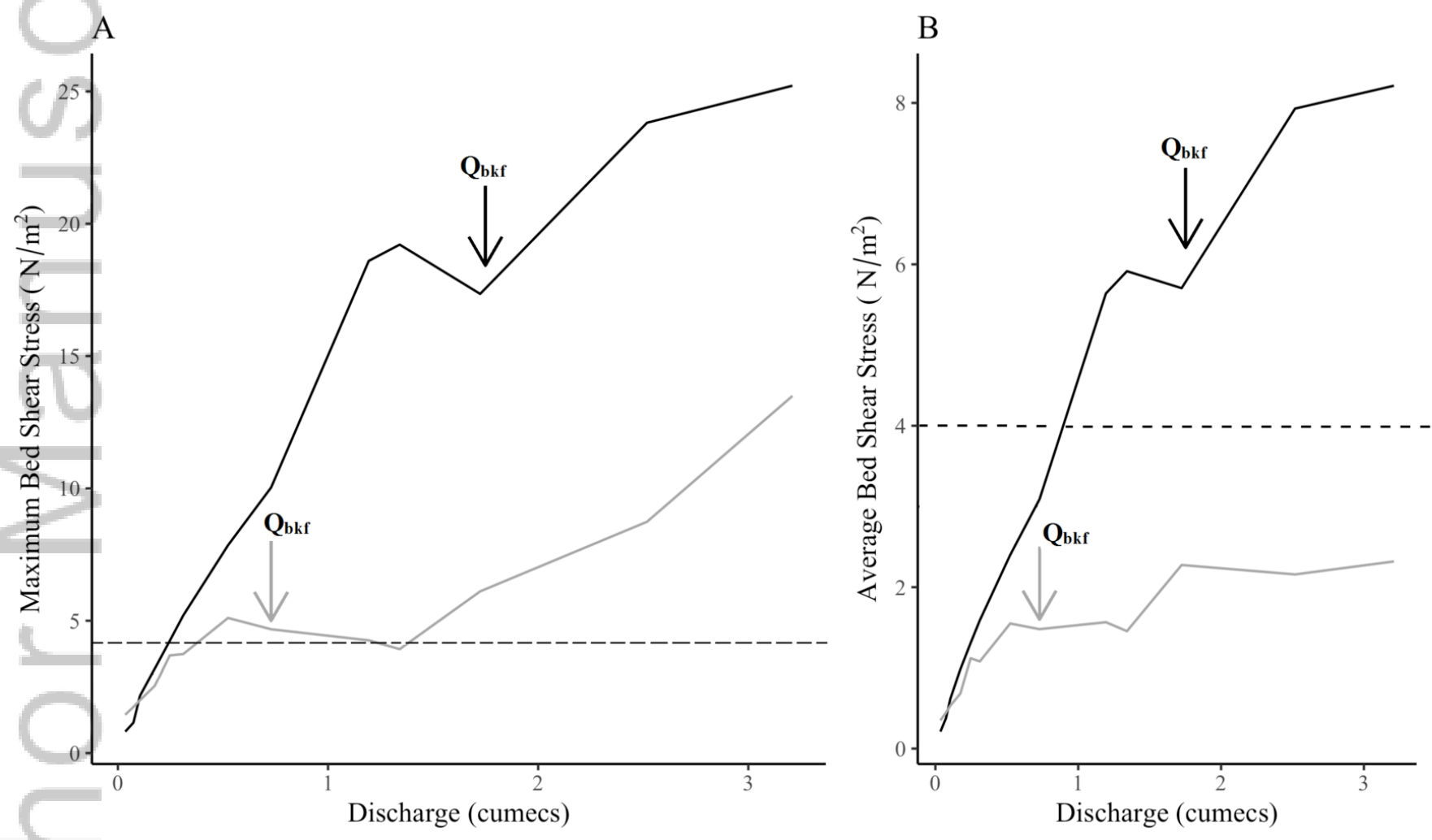

- Urban

- Non-Urban

RRA_3293_f3.tiff

This article is protected by copyright. All rights reserved. 


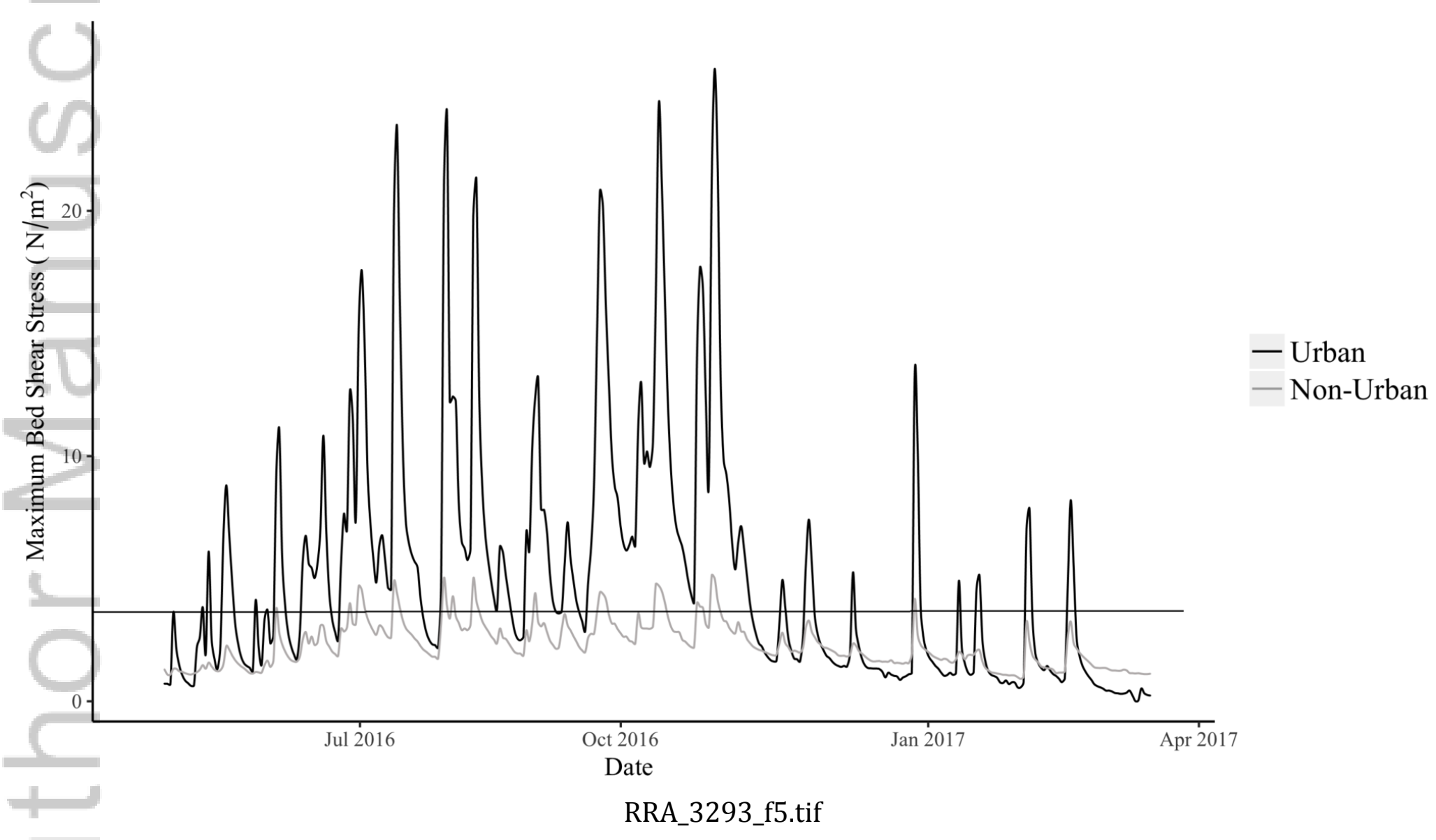

This article is protected by copyright. All rights reserved. 
A
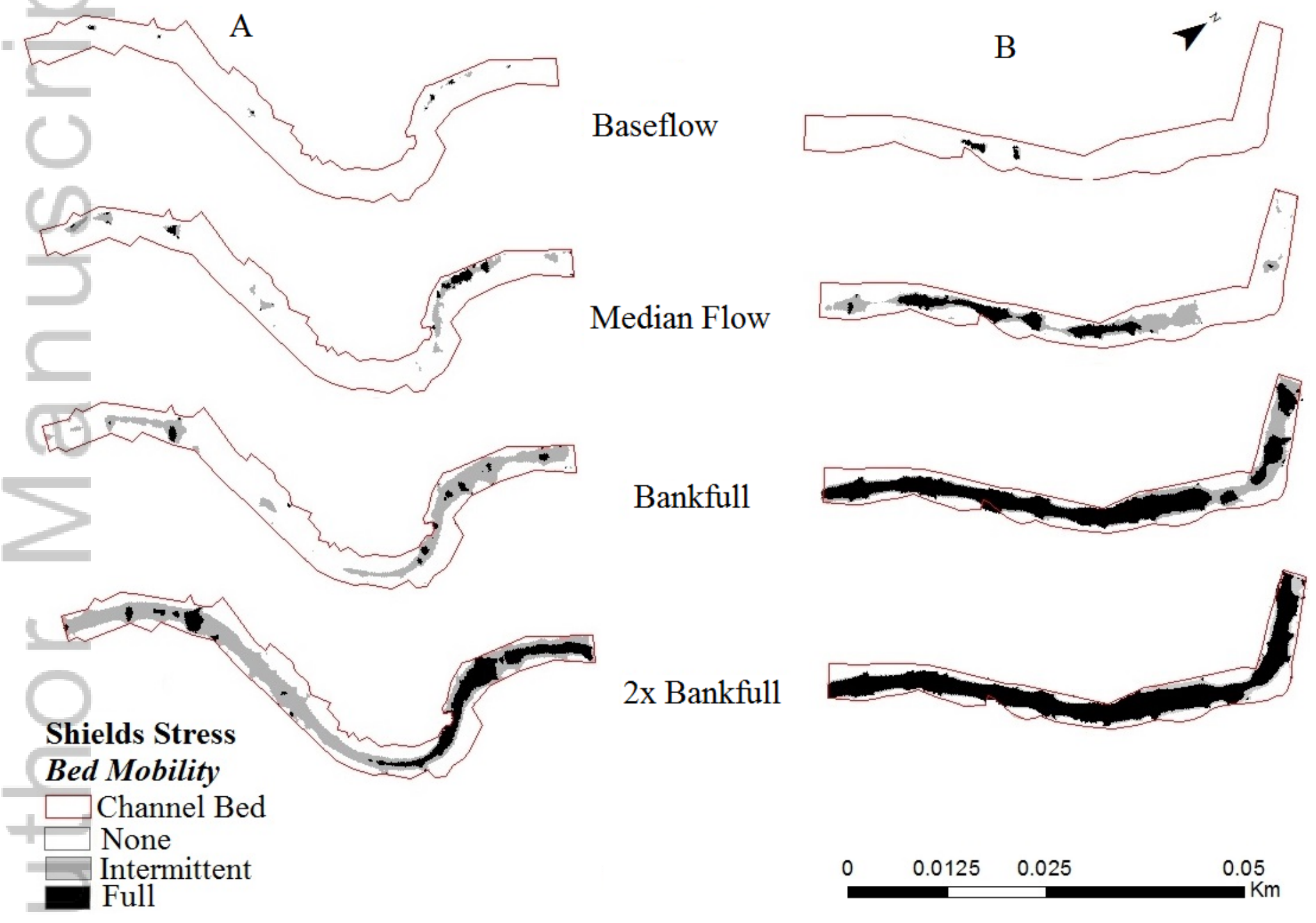

Shields Stress

Channel Bed

None

Full
Median Flow

Baseflow

Bankfull

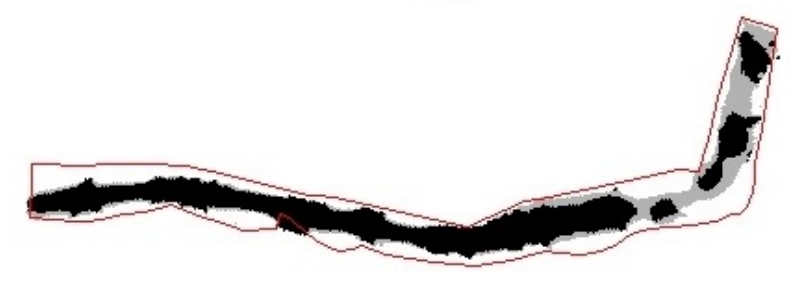

2x Bankfull

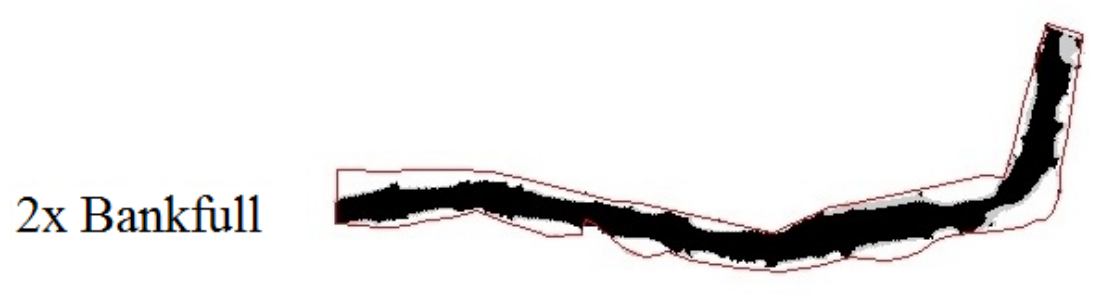

0 $0.0125 \quad 0.025$ 0.05

RRA_3293_66.tif

This article is protected by copyright. All rights reserved. 

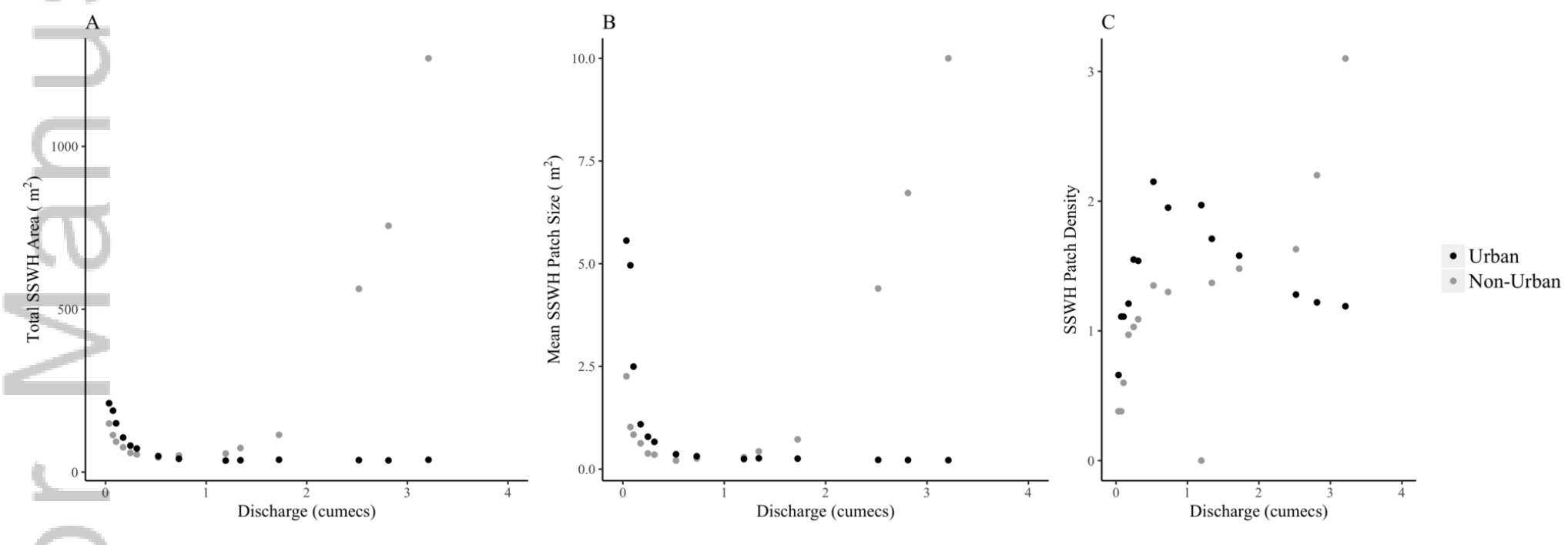

RRA_3293_f7.tiff 
A

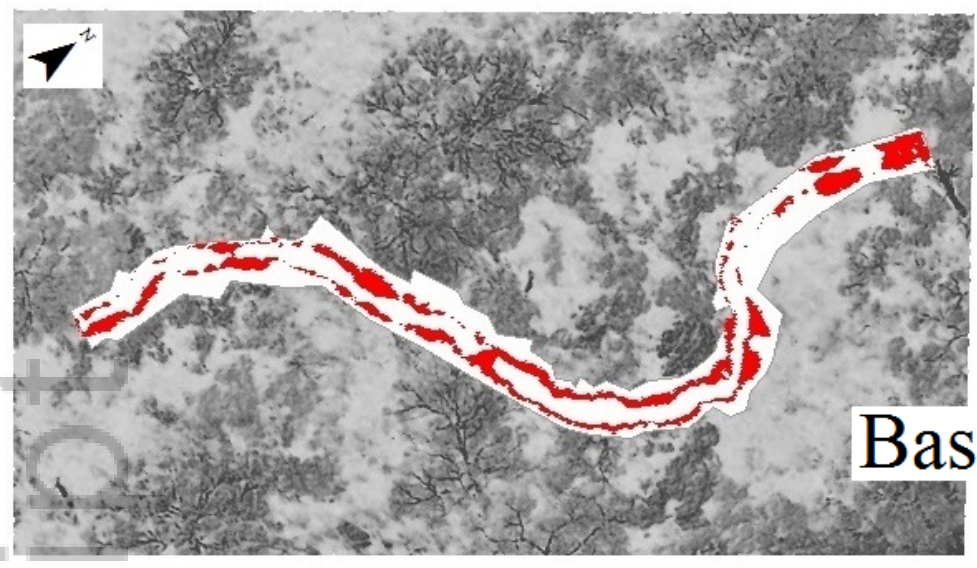

B
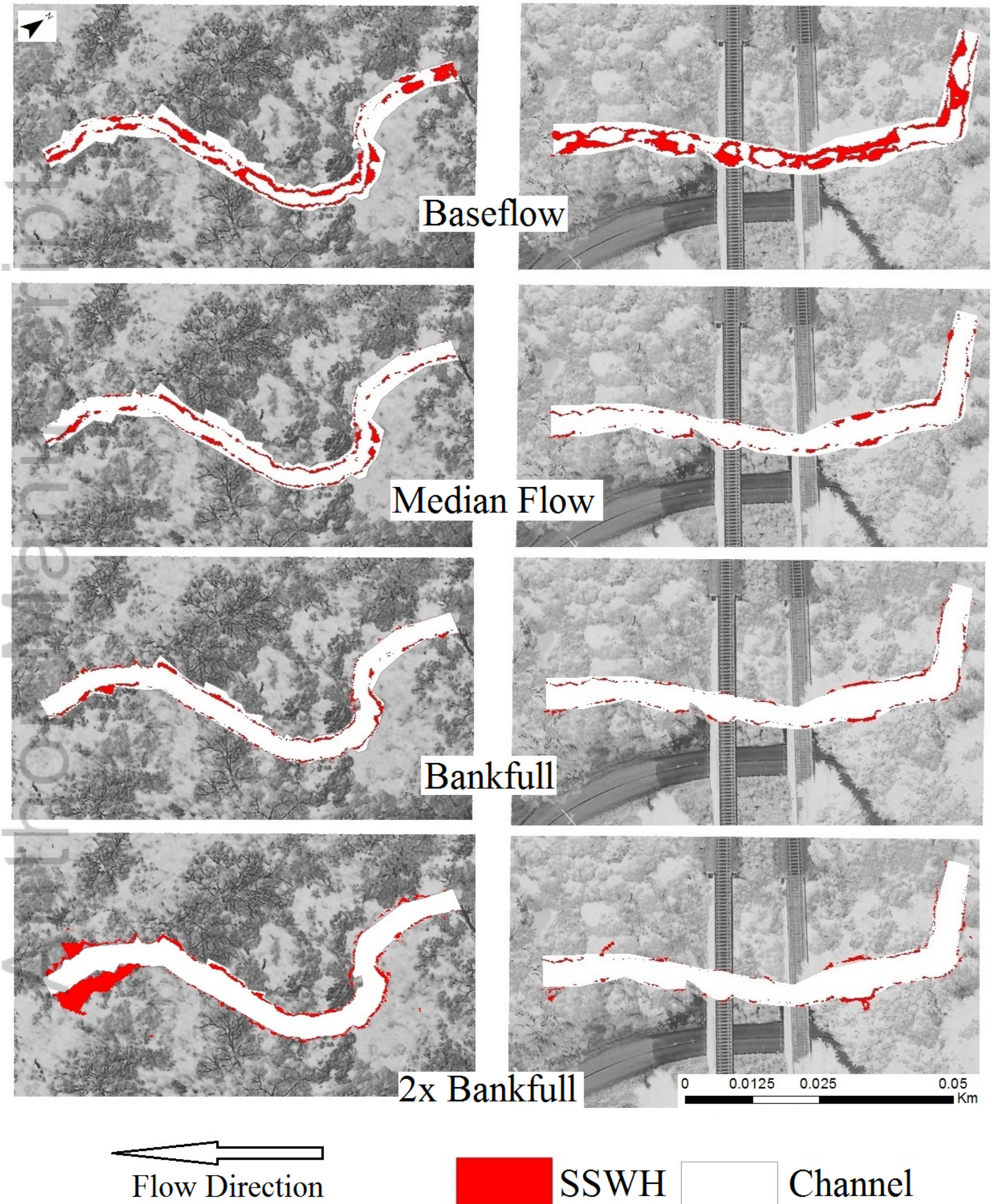

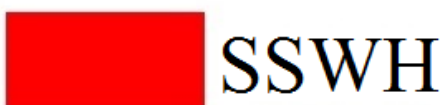

Channel 


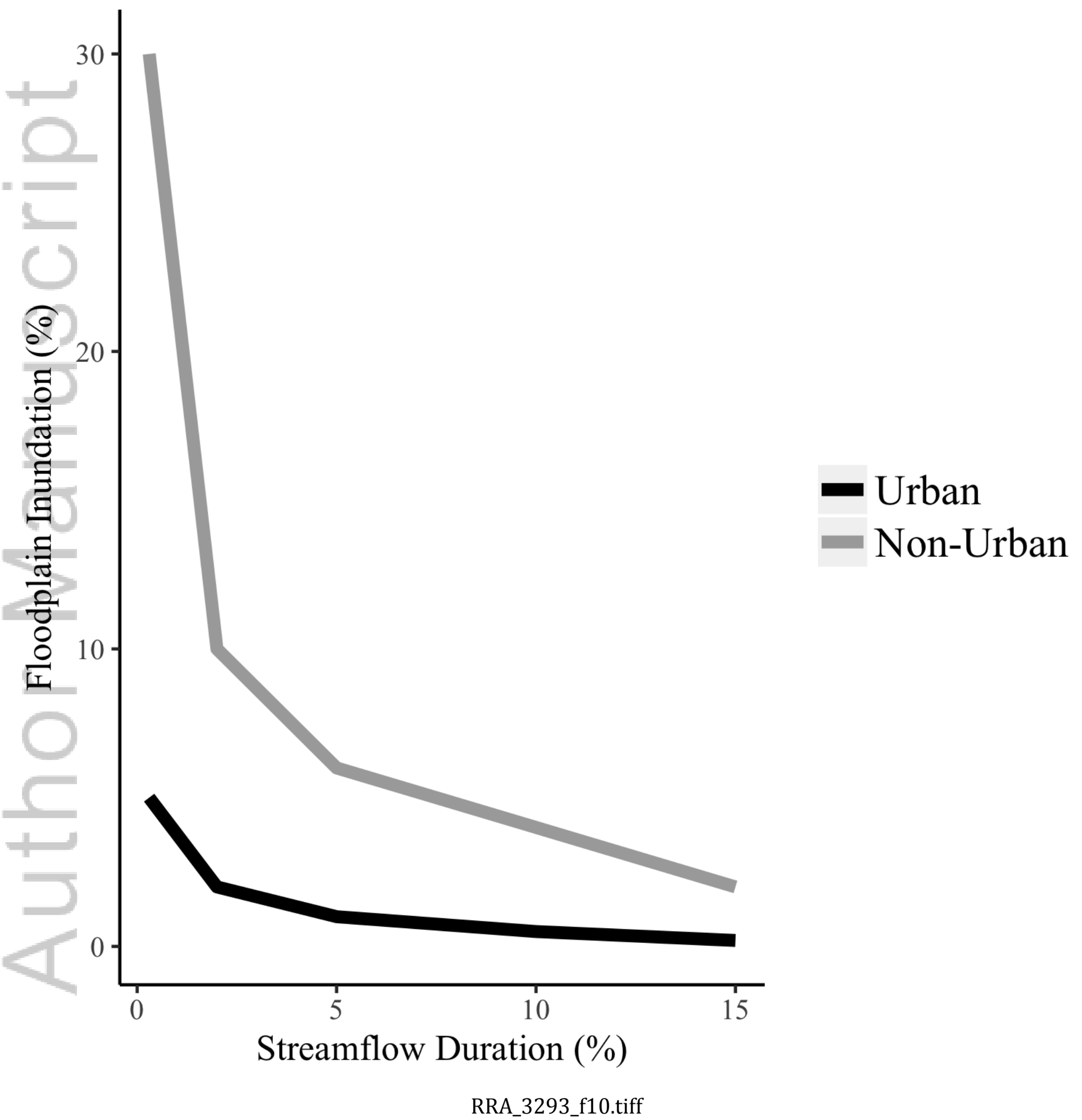

This article is protected by copyright. All rights reserved. 
A

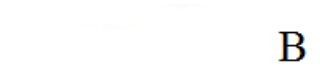

$15 \%$
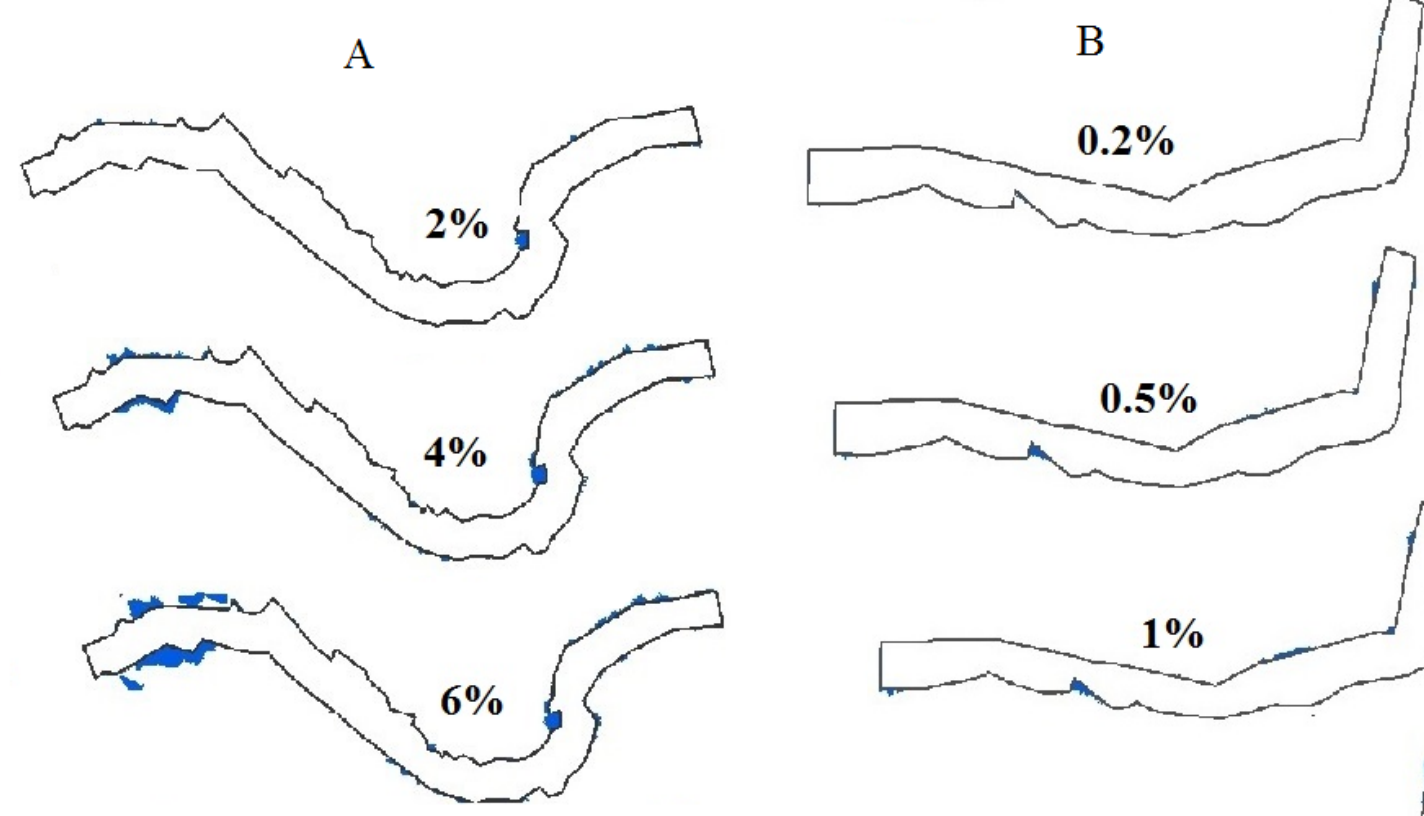

$10 \%$

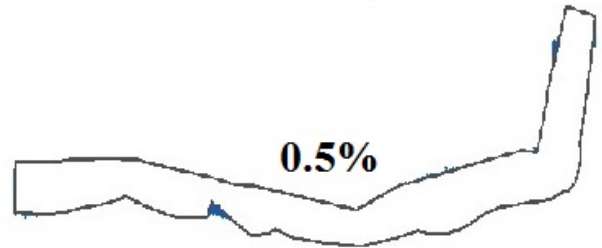

$5 \%$
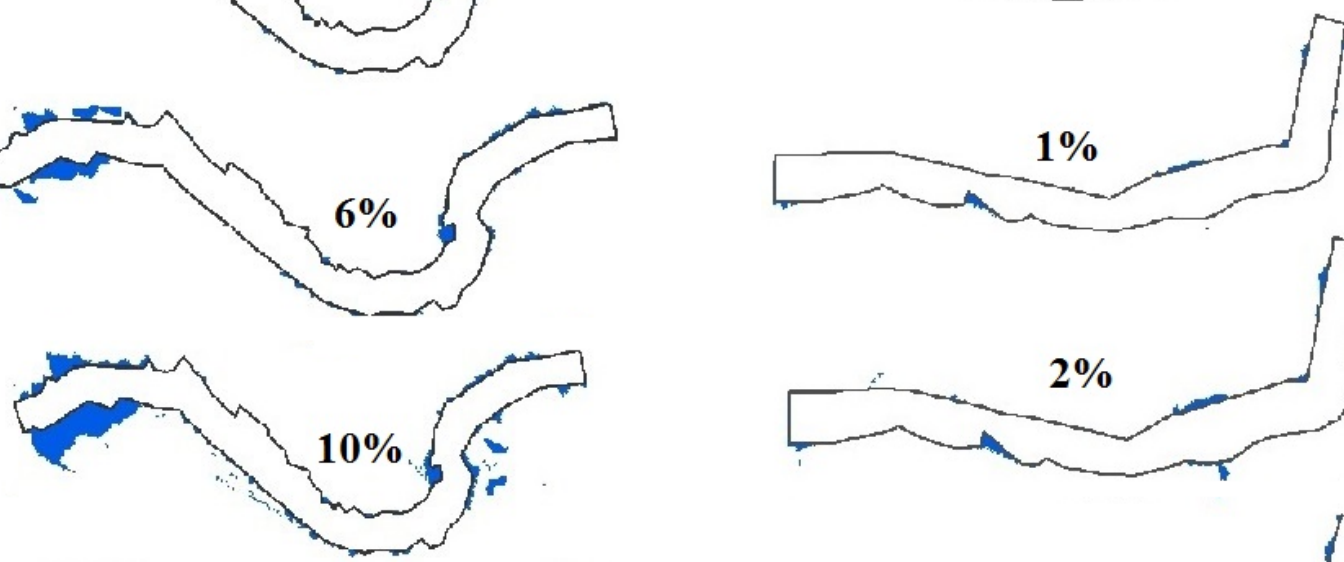

$2 \%$
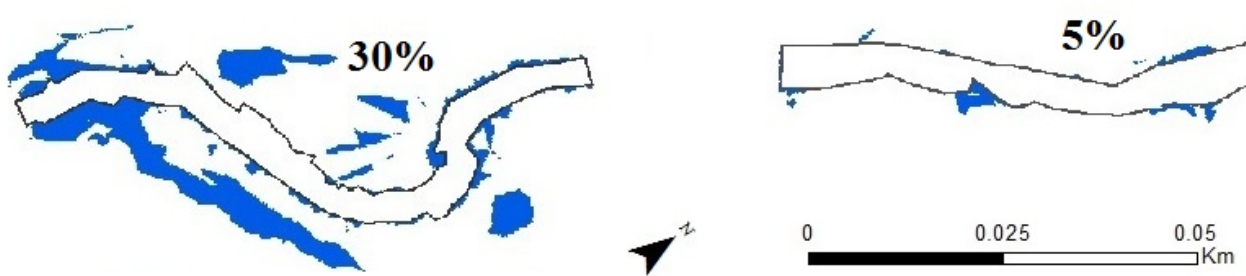

RRA_3293_f11.tif 


\section{University Library}

\section{- M M I E R R V A gateway to Melbourne's research publications}

Minerva Access is the Institutional Repository of The University of Melbourne

Author/s:

Anim, DO;Fletcher, TD;Vietz, GJ;Pasternack, GB;Burns, MJ

Title:

Effect of urbanization on stream hydraulics

Date:

2018-09-01

Citation:

Anim, D. O., Fletcher, T. D., Vietz, G. J., Pasternack, G. B. \& Burns, M. J. (2018). Effect of urbanization on stream hydraulics. RIVER RESEARCH AND APPLICATIONS, 34 (7), pp.661-674. https://doi.org/10.1002/rra.3293.

Persistent Link:

http://hdl.handle.net/11343/284023 